\title{
DAMPAK PERUBAHAN ORGANISASIONAL INSTITUSI PENDIDIKAN TINGGI KESEHATAN DALAM PERSPEKTIF

\author{
MANAJEMEN
}

\author{
Nang Randu Utama \\ Email: naratama_nru@yahoo.com \\ Politeknik Kesehatan Kemenkes Palangka Raya \\ Jalan George Obos No. 30-32 Palangka Raya
}

\begin{abstract}
This study aims to obtain a picture of the impact of organizational changes in the institution of higher health education in the management perspective that occurred in the scope of educational institutions belong to the Ministry of Health of the Republic of Indonesia. This study used a qualitative approach by conducting case study at Palangka Raya Health Polytechnic. The results of the study are as follows: (1) organizational change resulted in changes in the organizational structure; (2) organizational change also resulted in changes in the construction of facilities and infrastructure; (3) work system is no longer leads to routine, more dynamic, and flexible; (4) efficiency in learning and budget planning is done through a single door and centralized including personnel affairs, finance and general administration (ADUM) and academic and student affairs administration (ADAK); (5) organizational change is also accompanied by changes in the behavior of members of the organization, (6) organizational change is also related to leadership factors; and (7) organizational change also affect all forms of services that exist within the organization.
\end{abstract}

Keyword: change, organizational change, health polytechnic

\begin{abstract}
Abstrak: Penelitian ini bertujuan untuk memperolah gambaran mengenai dampak perubahan organisasional institusi pendidikan tinggi kesehatan dalam perspektif manajemen yang terjadi di lingkup institusi pendidikan Kementerian Kesehatan Republik Indonesia. Penelitian ini menggunakan pendekatan kualitatif dengan melakukan studi kasus pada institusi Politeknik Kesehatan Kemenkes Palangka Raya dalam perspektif manajemen. Hasil penelitian adalah: (1) perubahan organisasi mengakibatkan perubahan pada struktur organisasi; (2) perubahan organisasi juga mengakibatkan perubahan pada pembangunan sarana dan prasarana; (3) perubahan pada sistem kerja yang tidak lagi mengarah pada rutinitas, namun lebih dinamis, dan fleksibel; (4) terjadi efisiensi dalam pembelajaran dan perencanaan anggaran yang dilakukan melalui satu pintu dan terpusat termasuk Urusan Kepegawaian, Keuangan dan Administrasi umum (ADUM) dan Administrasi Akademik dan Kemahasiswaan (ADAK); (5) perubahan organisasi juga disertai dengan perubahan perilaku anggota organisasi;
\end{abstract}

Kehidupan suatu organisasi sangat erat sekali kaitannya dengan tuntutan organisasi dan kebutuhan anggotanya. Oleh karena itu, sebuah organisasi tidak akan mampu mencapai tujuan dan memenuhi kebutuhan organisasi dan anggotanya apabila organisasi ini dijalankan tanpa manajemen yang baik. Sehingga dalam hal ini dapat dikatakan bahwa kehidupan dalam organisasi sangat terkait erat dengan manajemen. Menurut Syafaruddin (2008) organisasi adalah sebuah sistem dan sistem merupakan satu rangkaian dari unsur-unsur yang saling terkait disatukan oleh desain untuk mencapai beberapa tujuan. Seperti halnya organisasi dapat dipandang sebagai sistem sosial sebab organisasi bergantung atas hubungan timbal balik diantara sejumlah orang. Hatch menjelaskan bahwa organisasi memang dapat didefinisikan dengan berbagai cara dan dapat dilihat sebagai struktur sosial, teknologi, kultur, struktur fisik, atau bagian 
(subsistem) dari lingkungan (Kusdi, 2009). Namun unsur yang menentukan dalam sebuah organisasi adalah purpose, people, dan plan. Sedangkan Kreitner dan Kinicki menambahkan bahwa suatu organisasi mengandung empat karakteristik, yaitu: (1) adanya koordinasi usaha; (2) mempunyai tujuan bersama; (3) terdapat pembagian kerja; dan (4) adanya hierarki kekuasaan (Wibowo, 2008).

Perubahan organisasi dapat dibedakan menjadi dua macam, yaitu: perubahan terencana (planned change) dan perubahan tidak terencana (unplanned change). Menurut Robbins (2002) pengertian perubahan terencana adalah berbagai upaya perubahan yang bersifat proaktif dan secara sengaja dilakukan organisasi (proactive and purposeful change). Dikatakan proaktif karena pengelola organisasi melakukan suatu perubahan terencana dalam rangka mengantisipasi tantangan yang bakal dihadapi organisasi di masa mendatang. Lebih lanjut Robbins (2002) mengemukakan bahwa tujuan dari perubahan yang direncanakan adalah untuk memperbaiki organisasi yang ada, untuk menyesuaikan diri dengan perubahan-perubahan yang terjadi di lingkungannya; dan untuk mengubah perilaku para karyawan. Mengingat pula bahwa sukses atau kegagalan sesuatu organisasi pada dasarnya tergantung pula pada hal-hal yang dilaksanakan oleh para karyawan, atau gagal melaksanakannya, maka perubahan yang direncanakan juga berkaitan dengan upaya mengubah perilaku para individu dan kelompok di dalam sesuatu organisasi.

Hal ini juga sebagaimana dijelaskan oleh King dan Anderson menyebutkan bahwa secara manajemen, perubahan harus direncanakan, khususnya perubahan kepada cara-cara organisasi berhubungan dengan lingkungan dan bagian tertentu dari organisasi berhubungan dengan yang lain (Syafaruddin, 2008). Winardi (2009) menyatakan bahwa contoh-contoh perubahan yang direncanakan, misalnya diintroduksinya tim-tim kerja; pengambilan keputusan yang sentralisasi; dan kultur-kultur keorganisasian baru. Organisasi berubah karena memang harus berubah, yaitu dipicu oleh faktor internal dan/ atau eksternal. Hal ini sesuai dengan gagasan teori sistem yang melandasi perspektif modern, bahwa suatu sistem cenderung mempertahankan ekuilibrium atau keseimbangan. Artinya, suatu sistem (termasuk dalam hal ini organisasi), tanpa ada dorongan faktor-faktor internal dan eksternal tertentu, niscaya memilih untuk tidak berubah dan lebih cenderung bertahan dalam keadaan semula (Kusdi, 2009).

Berdasarkan penjelasan mengenai perubahan organisasi tersebut di atas, maka dalam penelitian ini mengkaji perubahan yang terjadi pada organisasi pendidikan yang ada di lingkungan Kementerian Kesehatan Republik Indonesia dimana telah terjadi perubahan yang besar dan mendasar pada organisasi dan sistem manajemen pengelolaannya. Di Indonesia terdapat banyak institusi pendidikan kesehatan yang secara khusus menghasilkan tenaga kesehatan dalam berbagai jenis keahlian profesi dibidang kesehatan. Dalam hal ini institusi pendidikan tenaga kesehatan yang menjadi fokus dalam pembahasan ini adalah Institusi Pendidikan Tinggi Tenaga Kesehatan yang langsung berada di bawah Kementerian Kesehatan (yang sebelumnya disebut Departemen Kesehatan) Republik Indonesia. Hal ini berlaku sejak pemerintah melalui Peraturan Presiden Nomor 47 Tahun 2009 tentang Pembentukan dan Organisasi Kementerian Negara, mengubah semua bentuk Departemen, Kantor Menteri Negara dan Kantor Menteri Koordinator menjadi Kementerian Negara.

Reformasi pendidikan di Indonesia telah membawa dampak besar dalam berbagai aspek pendidikan dalam semua tingkat pendidikan termasuk dalam pengembangan lembaga pendidikan itu sendiri. Hal tersebut juga terjadi pada lembaga pendidikan tinggi tenaga kesehatan di lingkungan Kementerian Kesehatan Republik Indonesia. Berdasarkan laporan data yang ada pada Pusat Pendidikan Tenaga Kesehatan Depkes diketahui bahwa sampai pada permulaan tahun 2001 terdapat 203 lembaga pendidikan tinggi tenaga kesehatan berbentuk Akademi-Akademi Kesehatan yang menyelenggarakan Program Pendidikan Diploma III dalam berbagai bidang profesi kesehatan. Seluruh institusi pendidikan tinggi tenaga kesehatan yang menjadi fokus dalam pembahasan ini merupakan Unit Pelaksana Teknis (UPT) ini berada langsung dibawah Badan Pengembangan dan Pemberdayaan Sumberdaya 
Manusia Kesehatan Kementerian Kesehatan Republik Indonesia atau disingkat Badan PPSDM Kesehatan Kemenkes.

Akhir tahun 2001 telah terjadi gelombang reformasi yang telah membawa perubahan besar pada hampir semua Akademi Kesehatan di bawah Kementerian Kesehatan di seluruh Indonesia tersebut. Reformasi pendidikan dimulai dengan diterbitkasnnya Keputusan Menteri Kesehatan Nomor 298/Menkes-Kesos/SK/IV/2001 tentang Organisasi dan Tata Kerja Politeknik Kesehatan; dan Keputusan Menteri Kesehatan Nomor 1207/ Menkes/SK/XI/2001 tentang Pembentukan Politeknik Kesehatan Malang, Palangkaraya, Surabaya, Banda Aceh, Ambon, dan Ternate, yang merupakan suatu penggabungan dan perubahan bentuk kelembagaan dari beberapa jenis perguruan tinggi tenaga kesehatan berbentuk akademi yang kemudian digabung dan berubah menjadi sebuah institusi pendidikan tinggi dengan nama Politeknik. Terkait dengan tuntutan akan perubahan organisasi yang memang harus dilakukan pada segenap institusi pendidikan tinggi di lingkungan Kementerian Kesehatan, maka sebagai unit pelaksana teknis yang berada di bawah Badan Pengembangan dan Pemberdayaan Sumber Daya Manusia Kesehatan pada Kementerian Kesehatan Republik Indonesia, telah dipahami bahwa semua lembaga pendidikan yang berada di bawahnya hanya menerima saja apa yang menjadi kebijakan dari pihak luar sebagai organisasi yang memiliki kewenangan besar dan terpusat dalam proses perubahan ini.

Perubahan organisasi yang terjadi di lingkungan institusi pendidikan tinggi tenaga kesehatan ini dapat dikatakan juga tergolong sebagai perubahan terencana yang ditandai dengan dikeluarkannya Keputusan Menteri Kesehatan tersebut yang secara serentak terjadi penggabungan dan perubahan bentuk pada lembaga pendidikan tinggi tenaga kesehatan di seluruh Indonesia. Berdasarkan data yang dimuat dalam buku Rencana Aksi dari Badan Pengembangan dan Pemberdayaan Sumber Daya Manusia Kesehatan Depkes disebutkan bahwa secara keseluruhan jumlah institusi pendidikan tinggi tenaga kesehatan sampai dengan akhir Desember 2005 tercatat ada 32 Poltekkes Depkes yang tersebar di masing- masing propinsi di seluruh Indonesia. Kemudian tahun 2008 dibentuk lagi satu Poltekkes di Ternate dengan nama Politeknik Kesehatan Depkes Ternate. Sampai saat ini jumlah institusi pendidikan tinggi tenaga kesehatan yang ada di lingkungan Kementerian Kesehatan Republik Indonesia yang telah terbentuk adalah 33 Institusi Poltekkes Kemenkes dengan program pendidikan profesional dalam sejumlah bidang kesehatan masing-masing.

Sehubungan dengan penyelenggaraan pendidikan dimaksud, Kemenkes mengacu pada berbagai peraturan perundang-undangan, yaitu: (1) Undang-undang Nomor 20 Tahun 2003 tentang Sistem Pendidikan Nasional; (2) Undang-undang Nomor 23 Tahun 1992 tentang Kesehatan; (3) Peraturan Pemerintah Nomor 32 Tahun 1996 tentang Tenaga Kesehatan; dan (4) Peraturan Menteri Kesehatan Nomor 1192 1192/MENKES/PER/X/2004 tentang Pendirian Pendidikan Diploma Bidang Kesehatan. Selain itu dijelaskan bahwa tugas Poltekkes Kemenkes adalah melaksanakan pendidikan profesional dalam program Diploma I, Diploma II, Diploma III, dan/atau Program Diploma IV sesuai peraturan perundang-undangan yang berlaku. Dalam hal ini telah diketahui bahwa seluruh politeknik kesehatan di lingkungan Kementerian Kesehatan Republik Indonesia merupakan unit pelaksana teknis yang berada dibawah dan bertanggung jawab kepada Kepala Badan Pengembangan dan Pemberdayaan Sumber Daya Manusia Kesehatan (Badan PPSDM Kesehatan). Setiap politeknik kesehatan tersebut dipimpin oleh seorang Direktur yang dalam melaksanakan tugasnya secara teknis fungsional dibina oleh Kepala Pusat Pendidikan Tenaga Kesehatan dan secara administratif dibina oleh Sekretaris Badan PPSDM Kesehatan.

Perkembangan selanjutnya juga tidak dapat dipungkiri bahwa dampak dari kebijakan yang dibuat dalam perubahan bentuk kelembagaan ini harus disikapi dengan lebih bijaksana terutama yang menyangkut faktor struktur organisasi yang meliputi faktor kepemimpinan, budaya organisasi termasuk budaya anggota organisasinya, dan iklim organisasi dalam lingkup perubahan yang terjadi baik sebelum dilakukan penggabungan maupun sesudah penggabungan dalam satu 
kesatuan unit yang lebih besar tersebut. Selain itu proses perubahan ini juga merupakan bentuk upaya adaptasi terhadap perkembangan ilmu, pengetahuan dan teknologi khususnya dibidang kesehatan. Perubahan lembaga karena bentuk lembaga mengalami perubahan dari bentuk akademi kesehatan menjadi politeknik kesehatan. Institusi ini telah mengalami perubahan nama dan bentuk lembaga dimana pada prinsipnya merupakan gabungan dari beberapa institusi pendidikan berbentuk akademi kesehatan, yaitu Akademi Keperawatan Palangka Raya, Akademi Kebidanan Palangka Raya, dan Akademi Gizi Palangka Raya yang pada kemudian berubah menjadi sebuah instistusi baru dengan nama Politeknik Kesehatan Palangka Raya.

Perubahan yang terjadi dapat terlihat dengan adanya perubahan struktur organisasi dimana perubahan posisi Direktur pada institusi sebelumnya yaitu pada Akademi Keperawatan, Akademi Kebidanan, dan Akademi Gizi menempati posisi menjadi Ketua Jurusan saja, sedangkan untuk posisi Direktur yang baru dipilih melalui proses pemilihan kembali. Dengan adanya penggabungan lembaga maka jumlah pegawai juga tampak semakin besar. Kemudian juga terjadi perubahan fisik organisasi dimana setelah digabungkannya ketiga lembaga ini maka sekarang tampak lebih besar dengan pembangunan gedung dan fasilitas yang menjadi satu kesatuan. Perubahan pada teknologi yang digunakan juga dapat dilihat dengan diperkenalkan dan mulainya para tenaga pengajar menggunakan peralatan modern dalam proses belajar mengajar. Perubahan juga tampak pada perilaku anggota organisasi dimana tampak bahwa dengan organisasi yang semakin besar maka kegiatan-kegiatan organisasi menuntut mereka bekerja lebih keras dan cepat.

Berdasarkan uraian di atas, peneliti menekankan pemaknaan kasus yang diperoleh dari sudut pandang manajemen sebagai bagian dari anggota organisasi yang mempunyai kewenangan dan duduk sebagai pengelola organisasi. Oleh karena itu, fokus penelitian ini adalah mengkaji berdasarkan perspektif manajemen terhadap dampak perubahan organisasi yang terkait dengan perubahan organisasi pendidikan tinggi yang terjadi pada Politeknik Kesehatan Kemenkes
Palangka Raya sebagai salah satu bentuk lembaga pendidikan tinggi tenaga kesehatan yang baru dibentuk tersebut.

\section{METODE}

Penelitian ini menggunakan pendekatan kualitatif dengan melakukan studi kasus pada institusi Politeknik Kesehatan Kemenkes Palangka Raya dalam perspektif manajemen. Teknik pengumpulan data menggunakan wawancara mendalam, observasi dan studi dokumentasi. Peneliti mengamati dan terlibat langsung sehingga dapat melihat, mengetahui, merasakan, dan mengalami sendiri terhadap fenomena yang ada. Penelitian dilakukan dengan tujuan untuk memperoleh penghayatan dan keterlibatan langsung dimana peneliti bertindak sebagai instrumen kunci. Oleh karena itu, peneliti harus mampu menyesuaikan diri dan melakukan interaksi yang tepat dan baik dengan subyek penelitian sebagai sumber informasi. Penentuan sumber data yang menjadi informan kunci dilakukan secara purposive, kemudian dalam memperoleh data yang mendalam juga dipilih dan dijaring informan lainnya dengan teknik bola salju (snowball sampling).

Adapun yang menjadi informan dalam penelitian ini adalah dari unsur pengelola organisasi yang ada pada level pimpinan institusi seperti direktur, para pembantu direktur, ketua jurusan, dan ketua program studi serta pada level pengelola bidang atau unit penunjang organisasi. Data yang terkumpul melalui ketiga teknik tersebut diorganisasi, ditafsir, dan dianalisis secara berulang melalui analisis interaktif untuk menyusun konsep dan abstraksi temuan penelitian. Pengecekan kredibilitas data dilakukan dengan teknik trianggulasi, pengecekan anggota, dan perpanjangan waktu pengamatan. Data yang dinyatakan kredibel melalui triangulasi akan memberikan keyakinan terhadap peneliti tentang keabsahan datanya, sehingga tidak ragu dalam pengambilan kesimpulan penelitian (Gunawan, 2015). 


\section{HASIL}

Temuan penelitian dalam perspektif manajemen terhadap dampak perubahan yang terjadi pada Politeknik Kesehatan Kemenkes Palangka Raya dikemukakan menjadi tujuh temuan. Pertama, perubahan organisasi mengakibatkan perubahan pada struktur organisasi. Hal ini ditandai dengan perampingan struktur organisasi dimana hanya ada satu direktur dan tiga pembantu direktur. Kemudian terdapat ketua jurusan di masing-masing jurusan. Kedua, untuk alasan efisiensi, maka pelaksanaan urusan-urusan lembaga dalam pembelajaran dan perencanaan anggaran dilakukan melalui satu pintu dan terpusat termasuk Urusan Kepegawaian, Keuangan, dan Administrasi Umum (ADUM) dan Administrasi Akademik dan Kemahasiswaan (ADAK). Ketiga, sistem kerja tidak lagi mengarah pada rutinitas, namun lebih dinamis dan fleksibel sehingga pengembangan dapat dilakukan sesuai kebutuhan misalnya dalam pengembangan SDM dan kurikulum.

Keempat, perubahan organisasi juga mengakibatkan perubahan pada pembangunan sarana dan prasarana yang semakin luas, besar dan bagus. Kelima, dengan adanya perubahan organisasi maka perubahan juga terkait dengan faktor kepemimpinan. Pimpinan harus mempunyai visi-misi. Kemudian pimpinan harus bisa mengakomodir seluruh jurusan baik dari staf dosen maupun staf administrasinya. Selain itu juga pimpinan bisa menjalin kerjasama dengan pihak luar atau stake holder misalnya pemerintah provinsi, pemerintah kota, organisasi masyarakat, Lembaga Swadaya Masyarakat (LSM), organisasi profesi. Artinya melakukan kerjasama bisa ke dalam dan ke luar organisasi.

Keenam, perubahan organisasi juga disertai dengan perubahan perilaku anggota organisasi. Apabila mindset mereka selalu kembali pada pola lama maka susah untuk menyesuaikan diri dalam organisasi yang baru sehingga diperlukan capacity building sampai kelihatan mereka bisa menerima. Ketujuh, perubahan organisasi dapat berdampak pula pada segala macam bentuk layanan yang ada dalam organisasi, seperti tuntutan agar dilakukan manajemen terpadu atau layanan terpadu, misalnya layanan terpadu pada perpustakaan dan manajemen terpadu pada semua laboratorium yang ada.

\section{PEMBAHASAN}

Hasil temuan penelitian ini menunjukkan bahwa perubahan yang terjadi pada tingkat keorganisasian pada umumnya dinyatakan sebagai pengembangan organisasi (organizational development). Secara teknikal, istilah pengembangan organisasi berkaitan dengan setiap perubahan yang direncanakan, di dalam suatu organisasi. Tetapi dalam hal menafsirkan istilah tersebut secara populer biasanya dihubungkan dengan program pengembangan organisasi, yang berupaya untuk menimbulkan perubahanperubahan penting dalam organisasi, walaupun perubahan demikian dapat terjadi pada tingkat individual dan tingkat kelompok. Keputusankeputusan pada tingkat keorganisasian, biasanya diambil oleh pihak manajemen senior. Keputusan demikian kerap kali terjadi dalam rangka jangka panjang, dan mereka memerlukan perencanaan matang dalam pengimplementasiannya. Adapun contoh perubahan tersebut dapat berupa tindakan reorganisasi struktur dan tanggung jawab organisasi atau perombakan total organisasi atau perubahan-perubahan besar dalam sasaransasaran organisasi yang bersangkutan. Organisasi dapat membagi ulang tugas-tugasnya (Gunawan dan Benty, 2017).

Hal inilah yang terjadi pada organisasi pendidikan tinggi tenaga keseahatan yang ada di lingkungan Kementerian Kesehatan yaitu dengan dilakukuannya penggabungan dan perubahan bentuk lembaga dari akademi-akademi kesehatan menjadi politeknik kesehatan. Dewasa ini timbul kekuatan yang mendorong perubahan, termasuk perubahan besar dalam organisasi, sehingga menurut Kotter memerlukan transformasi melalui upaya-upaya reengineering, restructuring, quality programs, mergers and acquisitions, strategic change dan cultural change (Wibowo, 2008). Perubahan organisasional dapat terjadi pada struktur, teknologi, dan orang (Greenberg dan Baron, 2003). Di samping itu, menurut Robbins perubahan organisasi dapat pula terjadinya dalam 
pengaturan fisik (Wibowo, 2008). Sebagaimana dijelaskan bahwa struktur organisasi dapat didefinisikan sebagai bagaimana suatu tugas secara formal dibagi-bagi, dikelompokkan, dan diorganisasikan.

Syafaruddin (2008) menjelaskan bahwa perubahan bersifat aksiomatik bagi kehidupan organisasi. Organisasi akan belajar sehingga akan terjadi perubahan pada organisasi tersebut yang berasal dari hasil pengalaman (Gunawan, 2011). Suatu organisasi yang berhenti memberi respons secara efektif akan kehilangan keseimbangan keadaan stabilitas dan akan mengalami stagnasi. Keadaan yang sama juga berlaku bagi institusi pendidikan. Suatu organisasi semestinya akan selalu terkait dengan perubahan. Perubahan organisasi adalah perubahan dalam organisasi seperti menambahkan orang baru, memodifikasi suatu program atau perubahan organisasi yang meliputi suatu perubahan di dalam misi, susunan operasi, teknologi baru, dan kolaborasi. Secara khusus organisasi harus melakukan perubahan dalam organisasi itu sendiri untuk meningkatkan kinerja organisasi dan meninggalkan keterpurukan yang terjadi. Perubahan dalam organisasi berbeda-beda antara satu dengan yang lain tergantung pada karakteristisnya (ukuran, teknologi, dimensi-dimensi struktural, daur kehidupan, dan desain organisasi). Perubahan dalam organisasi dapat berlangsung dengan cara yang berbeda-beda.

Organisasi dengan adanya tuntutan tugas yang semakin kompleks, maka tampak para pegawai berusaha menyelesaikan tugas sampai di luar jam kerja. Perubahan juga terjadi pada beberapa agenda kegiatan organisasi yang mana sebelumnya dilakukan sendiri-sendiri, namun setelah terjadi penggabungan dan perubahan organisasi ini maka tampak dilakukan dalam waktu dan kegiatan secara bersama-sama contohnya, pada kegiatan penerimaan mahasiswa baru, praktik kerja lapangan dan penyelenggaraan wisuda. Sehingga sudah jelas dapat dikatakan bahwa telah terjadi perubahan dalam organisasi ini. Perubahan-perubahan dalam organisasi mencakup empat aspek, yaitu: (1) nama dan bentuk organisasi menjadi politeknik kesehatan; (2) struktur organisasi; (3) manajemen dalam pelaksanaan belajar mengajar, keuangan, sumber daya (pegawai dan mahasiswa); dan (4) bentuk fisik organisasi (sarana dan prasarana). Public sector organisations are now expected to shift policy towards greater competition and to apply private-sector style management practice to the public domain (Hossan, 2015).

Setiap organisasi akan mengalami perubahan dengan tujuan dan maksud yang berbeda-beda. Namun perubahan yang terjadi pada dasarnya terkait dengan faktor tuntutan kebutuhan yang harus dilakukan pada organisasi tersebut dan bertujuan untuk meraih kesuksesan. Menurut Hervey dan Brown perubahan adalah nama sebuah permainan dalam manajemen dewasa ini (Syafaruddin, 2008). Pasar, produk, dan suasana persaingan secara cepat terus berubah. Sebagai lingkungan yang berubah, semua organisasi mesti menyesuaikan diri bila ingin meraih kesuksesan. Perubahan organisasi tidak mungkin hanya dilakukan pada aspek makro (level organisasi dan unit) tanpa menyentuh aspek mikro (level individu) dari perilaku individu dalam organisasi. Terutama ketika perubahan tersebut menyangkut hal-hal besar, seperti visi-misi, strategi, dan desain struktur organisasi secara keseluruhan. Selain itu dalam perubahan-perubahan organisasi yang bersifat masif atau besar-besaran, maka aspek kultur atau budaya organisasi juga akan terkait.

Desain organisasi diubah pada beberapa elemen. Tanggung jawab departemen dikombinasikan, lapisan vertikal diubah dan rentang kendali diperluas dengan membuat organisasi lebih datar dan kurang birokrasi. Modifikasi desain struktural dari struktur sederhana ke struktur berbasis tim atau desain matriks. Job description, job enrichments, atau flexible work hours didefinisikan ulang. Modifikasi sistem kompensasi perlu dijalankan, demikian pula peningkatan motivasi melalui penghargaan. Perbaikan teknologi diarahkan pada pekerja yang lebih efisien. Manajemen sains mengimplementasikan perubahan berdasarkan time and motion study untuk meningkatkan efisiensi produksi. Perubahan teknologi biasanya menyangkut pengenalan peralatan baru, metode otomatisasi, atau komputerisasi. 
Pengaturan fisik dilakukan dengan mengatur tata letak ruang kerja. Manajemen mempertimbangkan kebutuhan kerja, kebutuhan interaksi formal dan kebutuhan sosial jika membuat keputusan tentang konfigurasi ruang, deesain interior, penempatan peralatan, dan lain-lain. Mengurangi tembok dan partisi dan desain kantor terbuka menjadi lebih mudah bagi karyawan saling berkomunikasi. Berdasarkan temuan penelitian diketahui bahwa perubahan organisasi akan mengakibatkan perubahan pada struktur organisasi. Hal ini ditandai dengan perampingan struktur organisasi dimana hanya ada satu direktur dan tiga pembantu direktur. Kemudian terdapat ketua jurusan di masingmasing jurusan. Masih terkait dengan perubahan pada struktur organisasi maka adanya perubahan organisasi menyangkut faktor kepemimpinan. Pimpinan harus mempunyai visi dan misi. Kemudian pimpinan harus bisa mengakomodasi seluruh jurusan baik dari staf dosen maupun staf administrasinya.

Selain itu juga pimpinan bisa menjalin kerjasama dengan pihak luar atau stakeholders misalnya pemerintah propinsi, pemerintah kota, organisasi masyarakat, LSM, dan organisasi profesi. Artinya melakukan kerjasama bisa ke dalam dan ke luar organisasi. Sehubungan dengan perubahan organisasi pada aspek perubahan teknologi juga terkait dengan perubahan pada pembangunan sarana dan prasarana yang semakin luas, besar dan bagus. Robbins menyatakan bahwa tujuan perubahan terencana di satu sisi untuk memperbaiki kemampuan organisasi untuk menyesuaikan diri dengan perubahan lingkungan dan di sisi lain mengupayakan perubahan perilaku karyawan (Wibowo, 2008). Perubahan perilaku dalam organisasi memerlukan proses belajar organisasi yang dilakukan melalui pendidikan, pengalaman, dan kegiatan individu (Kline dan Saunders, 1993; Senge, 1990). Organisasi melalui program pendidikan akan menghasilkan sumber daya yang mampu berpikir obyektif, kritis, kreatif, dan integratif tentang akar aspirasi demi membangun organisasi (Gunawan, 2008).

Sehubungan dengan perubahan organisasi yang terjadi akibat penggabungan organisasi, Sobirin (2009) menyebutkan dengan perumpamaan penggabungan tersebut sebagai sebuah perkawinan dimana memahami sifat karakter masing-masing pihak sebelum perkawinan tersebut dilaksanakan merupakan tindakan yang bijak mengingat perkawinan bukan sekedar bertemunya dua insan dalam pelaminan melainkan pertemuan dua sifat, karakter, kebiasaan dan budaya yang berbeda. Oleh karenanya kedua pihak perlu melakukan perubahan dan harmonisasi sifat, kebiasaan dan budaya agar perkawinan tersebut bisa berlangsung lama dan mencapai tujuan. Sedangkan Chatab (2009) menjelaskan bahwa budaya organisasi sangat berpengaruh dalam membentuk dan memberi arti kepada anggota organisasi untuk berperilaku dan bertindak, yang diturunkan dari satu generasi ke generasi berikutnya sebagai karakter organisasi. Untuk itu perlu dilakukan identifikasi dan interpretasi kekuatan dan jenis budaya yang dominan, ketidakserasian budaya dan arah perubahannya, serta fokus tindak lanjutnya guna peningkatan keefektifan organisasi dan kinerjanya. Organizational change to sustainability is treated by a number of different disciplines: among them are policy-oriented studies, focusing inter alia on the influence, and constraints of legislative influences (Brown, 2008; Barth dan Michelsen, 2013).

Perubahan organisasi juga disertai dengan perubahan perilaku anggota organisasi. Apabila mindset mereka selalu kembali pada pola lama maka susah untuk menyesuaikan diri dalam organisasi yang baru sehingga diperlukan capacity building sampai kelihatan mereka bisa menerima. Untuk alasan efisiensi, maka pelaksanaan urusanurusan lembaga dilakukan melalui satu pintu dan terpusat termasuk Urusan Kepegawaian, Keuangan, dan Administrasi umum (ADUM) dan Administrasi Akademik dan Kemahasiswaan (ADAK). Perubahan organisasi membawa pengaruh dalam pembelajaran dan perencanaan anggaran. Sistem kerja tidak lagi mengarah pada rutinitas, namun lebih dinamis dan fleksibel sehingga pengembangan dapat dilakukan sesuai kebutuhan misalnya dalam pengembangan SDM dan kurikulum. Perubahan organisasi dapat berdampak pula pada segala macam bentuk layanan yang ada dalam organisasi, seperti 
tuntutan agar dilakukan manajemen terpadu atau layanan terpadu, misalnya layanan terpadu pada perpustakaan dan manajemen terpadu pada laboratorium-laboratorium yang ada.

Dengan demikian, sasaran atau objek suatu perubahan dapat diarahkan pada struktur organisasi, teknologi, pengaturan fisik, proses, orang, dan budaya dalam suatu organisasi. Namun, sasaran perubahan tersebut pada umumnya tidak berdiri sendiri, melainkan merupakan kombinasi karena di antaranya saling mempengaruhi. Dijelaskan juga oleh Winardi (2008) bahwa target-target keorganisasian untuk perubahan termasuk, misalnya: manusia, teknologi, pekerjaan dan arus pekerjaan, struktur keorganisasian, proses-proses, kultur, dan manajemen. Jones dalam Winardi (2008) menyatakan bahwa perubahan keorganisasian yang terencana normal ditujukan ke arah upaya memperbaiki kinerja organisasi, yaitu: (1) sumber daya manusia; (2) sumber-sumber daya fungsional; (3) kemampuan teknologi; dan (4) kemampuan keorganisasian. Management of change methodology should be applied to design deviations and variances, as well as to preplanned changes (Mukharror, 2006).

\section{SIMPULAN}

Perubahan organisasi mengakibatkan perubahan pada struktur organisasi. Hal ini ditandai dengan perampingan struktur organisasi dimana hanya ada satu direktur dan tiga pembantu direktur. Kemudian terdapat ketua jurusan di masing-masing jurusan. Perubahan organisasi juga mengakibatkan perubahan pada pembangunan sarana dan prasarana yang semakin luas, besar dan bagus. Sistem kerja tidak lagi mengarah pada rutinitas, namun lebih dinamis dan fleksibel sehingga pengembangan dapat dilakukan sesuai kebutuhan misalnya dalam pengembangan SDM dan kurikulum. Selain itu perubahan organisasi membawa pengaruh dalam pembelajaran dan perencanaan anggaran, dengan kata lain untuk efisiensi, maka pelaksanaan urusan-urusan lembaga dilakukan melalui satu pintu dan terpusat termasuk urusan kepegawaian, keuangan dan administrasi umum (ADUM) dan Administrasi Akademik dan Kemahasiswaan
(ADAK). Perubahan organisasi juga disertai dengan perubahan perilaku anggota organisasi.

Apabila mindset mereka selalu kembali pada pola lama maka susah untuk menyesuaikan diri dalam organisasi yang baru sehingga diperlukan capacity building sampai kelihatan mereka bisa menerima. Dengan adanya perubahan organisasi maka perubahan juga terkait dengan faktor kepemimpinan. Pimpinan harus mempunyai visi-misi. Kemudian pimpinan harus bisa mengakomodir seluruh jurusan baik dari staf dosen maupun staf administrasinya. Selain itu juga pimpinan bisa menjalin kerjasama dengan pihak luar atau stakeholders misalnya pemerintah propinsi, pemerintah kota, organisasi masyarakat, LSM, organisasi profesi. Artinya melakukan kerjasama bisa ke dalam dan ke luar organisasi. Perubahan organisasi dapat berdampak pula pada segala macam bentuk layanan yang ada dalam organisasi, seperti tuntutan agar dilakukan manajemen terpadu atau layanan terpadu, misalnya layanan terpadu pada perpustakaan dan manajemen terpadu pada laboratoriumlaboratorium yang ada.

\section{DAFTAR RUJUKAN}

Barth, M., dan Michelsen, G. 2013. Learning for Change: An Educational Contribution to Sustainability Science. Sustain Sci, 8(2), 103119.

Brown, R. R. 2008. Local Institutional Development and Organizational Change for Advancing Sustainable Urban Water Futures. Environ Manage, 41(2), 221-233.

Chatab, N. 2009. Mengawal Rancangan Pilihan Organisasi. Bandung: Alfabeta.

Greenberg, J., dan Baron R. A. 2003. Behavior in Organization. New Delhi: Prentice Hall.

Gunawan, I. 2011. Evaluasi Program Pembelajaran. Jurnal Pendidikan, 17(1), 52-70.

Gunawan, I. 2015. Metode Penelitian Kualitatif: Teori dan Praktik. Jakarta: PT Bumi Aksara.

Gunawan, I. 24 Desember 2008. Pendidikan Perdamaian. Banjarmasin Pos, hlm. 6. 
Gunawan, I., dan Benty, D. D. N. 2017. Manajemen Pendidikan: Suatu Pengantar Praktik. Bandung: Alfabeta.

Hossan, C. 2015. Applicability of Lewin's Change Management Theory in Australian Local Government. International Journal of Business and Management, 10(6), 53-65.

Keputusan Menteri Kesehatan Nomor 1207/Menkes/ SK/XI/2001 tentang Pembentukan Politeknik Kesehatan Malang, Palangkaraya, Surabaya, Banda Aceh, Ambon, dan Ternate, (Online), (http://www.depkes.go.id/), 3 Mei 2016.

Keputusan Menteri Kesehatan Nomor 298/MenkesKesos/SK/IV/2001 tentang Organisasi dan Tata Kerja Politeknik Kesehatan, (Online), (https:// peraturan.bkpm.go.id/jdih/userfiles/batang/ KEPMENKES_298_2001.pdf), 2 Mei 2016.

Kline, P., dan Saunders, B. 1993. Ten Steps to a Learning Organization. Arlington: Great Ocean Publishers, Inc.

Kusdi. 2009. Teori Organisasi dan Administrasi. Jakarta: Salemba Humanika.

Mukharror, D. A. 2006. Management of Change: Case Study of Relief Header Redesign during Project Construction Phase. Journal of the Indonesian Oil and Gas Community, 1(1), 1-5.

Peraturan Menteri Kesehatan Nomor 1192/MENKES/ $\mathrm{PER} / \mathrm{X} / 2004$ tentang Pendirian Pendidikan Diploma Bidang Kesehatan, (Online), (http:// bppsdmk.kemkes.go.id/web/filesa/peraturan/51. pdf), 23 Juni 2016.
Peraturan Pemerintah Nomor 32 Tahun 1996 tentang Tenaga Kesehatan, (Online), (http://indonesia. go.id), diakses 23 Mei 2016.

Peraturan Presiden Nomor 47 Tahun 2009 tentang Pembentukan dan Organisasi Kementerian Negara, (Online), (http://indonesia.go.id), diakses 23 Mei 2016.

Robbins, S. P. 2002. Prinsip-prinsip Perilaku Organisasi. Terjemahan oleh Halida dan Dewi Sartika. Jakarta: Erlangga.

Senge, P. M. 1990. The Fifth Discipline: The Art and Practice of the Learning Organization. New York: Doubleday Business.

Sobirin, A. 2009. Budaya Organisasi: Pengertian, Makna, dan Aplikasinya dalam Kehidupan Organisasi. Yogyakarta: UPP-STIM YKPN.

Syafaruddin. 2008. Efektifitas Kebijakan Pendidikan: Konsep, Strategi, dan Aplikasi Kebijakan Menuju Organisasi Sekolah Efektif. Jakarta: Rineka Cipta.

Undang-undang Nomor 20 Tahun 2003 tentang Sistem Pendidikan Nasional. 2005. Bandung: Citra Umbara.

Undang-undang Nomor 23 Tahun 1992 tentang Kesehatan. 2000. Jakarta: Fokus Media.

Wibowo. 2008. Manajemen Perubahan. Jakarta: Rajawali Press.

Winardi, J. 2008. Manajemen Perubahan (Mangement of Change). Jakarta: Kencana. 